\title{
POTENSI KEJADIAN ROB DI PESISIR PROBOLINGGO SERTA PERBANDINGAN KONDISINYA ANTARA MUSIM BARAT DAN MUSIM TIMUR BERDASARKAN DATA OSEANOGRAFI DAN METEOROLOGI
}

\author{
THE POSSIBILITY OF TIDAL FLOOD ON PROBOLINGGO COASTAL AREA AND \\ ITS COMPARISON CONDITION BETWEEN WEST AND EAST SEASONS BASED \\ ON OCEANOGRAPHICAL AND METEOROLOGICAL DATA
}

\author{
Asep Sandra Budiman* dan Indarto Happy Supriadi \\ Pusat Penelitian Oseanografi LIPI, Jakarta, 14430, Indonesia \\ *E-mail: assandra81@gmail.com
}

\begin{abstract}
Tidal flood has become a serious problem in several coastal areas in Indonesia, particularly in Probolinggo, East Java Province - Indonesia. The study of tidal flood in the coastal area of Probolinggo was conducted by processing and analyzing oceanographical and meteorological data to asses the possibility and to compare its variability between the West and East seasons. Data is used for this study consist of tidal and wind data from Stamet II Perak Surabaya (7 years from 2004 2011); rainfall data from BMKG Juanda Surabaya (9 years from 2002 - 2011); and Probolinggo topography data from SRTM (Shuttle Radar Topography Mission - http://srtm.csi.cgiar.org/). Tidal flood occurrence possibility was determined by comparing the sea level heights with the topography of the study area. the meteorological data were analyzed to compare its variability during West and East seasons. Results show that tidal flood may occur at several points on the coast of Probolinggo while the high tide occurs especially during the spring tide since the sea level was higher $(0.73 \mathrm{~m})$ than the topography of the coastal area of Probolinggo $(<0.5 \mathrm{~m}$ by average). The condition becomes worse during the East season due to the existence of strong wind in the direction that contributes to generating a high wave in the coastal.
\end{abstract}

Keywords: meteorology, oceanography, Probolinggo, tidal flood

\begin{abstract}
ABSTRAK
Rob atau banjir pasang air laut telah menjadi permasalahan serius di beberapa daerah pesisir di Indonesia, khususnya Probolinggo. Kajian mengenai banjir rob di wilayah ini telah dilakukan dengan mengolah dan menganalisa data-data oseanografi dan meteorologi untuk mengkaji seberapa besar potensi kejadian dan perbandingan kondisinya saat musim Barat dan Timur. Data-data yang digunakan adalah data pasang-surut (pasut) dan angin wilayah Probolinggo selama 7 tahun (2004 - 2011) dari Stamet II Perak Surabaya, serta data topografi Probolinggo dari Shuttle Radar Topography Mission (SRTM). Potensi terjadinya banjir rob ditentukan dengan membandingkan tinggi muka air ini dengan topografi daerah kajian. Data meteorologi dianalisa untuk dibandingkan kondisinya saat musim Barat dan Timur. Hasil menunjukkan bahwa banjir rob dapat terjadi di beberapa titik di pesisir Probolinggo saat pasang tinggi khususnya selama periode pasang purnama akibat tinggi muka air yang lebih tinggi $(0,73 \mathrm{~m})$ daripada ketinggian topografi daerah kajian (rerata $<0.5 \mathrm{~m})$. Kondisi akan lebih buruk selama musim Timur akibat datangnya angin kencang dari arah yang berpotensi dalam kemunculan gelombang tinggi di pesisir.
\end{abstract}

Kata Kunci: banjir rob, meteorologi, oseanografi, Probolinggo

\section{PENDAHULUAN}

Rob atau banjir pasang air laut telah menjadi bencana alam yang telah me- nyebabkan berbagai kerugian di wilayah terdampak dan seringkali dikaitkan dengan bukti nyata efek kenaikan muka laut saat ini (Hinkel et al., 2014; Wdowinski et al., 2016; 
Buchanan et al., 2017; Dahl et al., 2017). Rob telah menjadi permasalahan di beberapa daerah pesisir di Indonesia. Fenomena rob yang terjadi di Indonesia telah menjadi bahan kajian antara lain adalah rob di wilayah pesisir utara Jakarta, Semarang, dan belakangan muncul pemberitaan mengenai Rob yang melanda wilayah pesisir Probolinggo (BPBD Kab. Probolinggo, 2016). Banjir rob sering terjadi di Kecamatan Kraksaan, Gending, dan Kalibuntu (Supriyadi and Sandra, 2015)

Kabupaten Probolinggo merupakan salah satu kabupaten yang terletak di Provinsi Jawa Timur dan secara geografis terletak pada $7^{\circ} 40^{\prime} \mathrm{LS}-8^{\circ} 10^{\prime} \mathrm{LS}$ dan $112^{\circ} 50^{\prime} \mathrm{BT}-113^{\circ} 30^{\prime} \mathrm{BT}$ dengan luas wilayah mencapai 1696,16 $\mathrm{km}^{2}$ (BPS Kab. Probolinggo, 2016). Bagian utara terdiri dari dataran-dataran rendah dan sering terkena banjir air pasang (KOMINFO SETDA PEMKAB Probolinggo, 2016). Penduduk di wilayah pesisir sendiri banyak yang bekerja sebagai petani tambak dan banjir rob ini telah banyak merugikan mereka. Tambak-tambak banyak yang rusak, tercatat puluhan rumah di 5 (lima) desa terendam, yaitu Desa Kalibuntu di Kraksaan, Desa Randutatah di Paiton, Desa Pajurangan di Gending, Desa Pesisir di Kecamatan Sumberasih, Desa Tongas di Kecamatan Tongas, dan sekitar 56,8 h tambak ikan dan garam rusak akibat banjir rob pada tahun 2016 (Rofiq, 2016; Wicahyo, 2016). Kusmanto et al. (2016) menyebutkan bahwa ada indikasi terjadinya amplifikasi pasang surut akibat resonansi periode alami Selat Madura yang mengakibatkan amplitudo pasang surut perairan Probolinggo mencapai $3 \mathrm{~m}$ dan mengakibatkan banjir rob.

Kabupaten Probolinggo memiliki dua siklus musim setiap tahunnya, yaitu musim kemarau dan musim penghujan. Diantara dua musim tersebut terdapat musim pancaroba yang biasanya ditandai dengan tiupan angin kering yang cukup kencang yang berhembus dari arah Tenggara ke Barat Laut biasa disebut "Angin Gending" (KOMINFO SETDA PEMKAB Probolinggo, 2016). Jumlah curah hujan setahun mencapai 1649 $\mathrm{mm}^{3}$. Jumlah curah hujan terbanyak terjadi di bulan April. Khusus untuk tahun 2015, hari hujan sebanyak 117 hari dengan intensitas tertinggi di bulan Februari, April dan Desember (BPS Kab. Probolinggo, 2016).

Parameter-parameter oseanografi yang ikut memicu terjadinya banjir rob di wilayah pesisir antara lain adalah gelombang dan kenaikan muka laut. Gelombang laut dapat menyebabkan banjir di wilayah pesisir yang rendah, dimana tinggi muka air ini merupakan kombinasi antara tinggi muka laut rerata atau MSL (Mean Sea Level), pasang surut, dan gelombang (Wolf, 2009). Maulana dan Hartanto (2010) menyatakan bahwa dalam kajian kerentanan pesisir, tinggi gelombang signifikan (significant wave height) menjadi suatu parameter yang berkaitan dengan bahaya penggenangan pesisir. Lebih jauh, banjir rob yang disertai badai, luapan sungai, dan gelombang tinggi dapat memberikan dampak kerusakan yang serius pada wilayah pesisir (NOAA, 2017).

Penelitian terkait banjir rob di Indonesia yang pernah dilakukan antara lain adalah penelitian mengenai rob di Kaligawe Semarang akibat perubahan elevasi muka laut saat kondisi hujan dan tidak hujan melalui model matematika oleh Wahyudi (2007) dan simulasi rob Semarang menggunakan model hidrodinamika 2D dengan memasukkan faktor-faktor meteorologi, laju penurunan tanah, dan pasang surut oleh Habibie et al. (2012), pengaruh genangan rob terhadap dinamika sosial ekonomi masyarakat kel. Bandarharjo Semarang oleh (Pratikno et al., 2014), banjir rob terkait potensi kerentanan lingkungan serta penanggulangannya oleh Zuardin (2017) dan model genangan banjir rob Semarang Utara oleh Handoyo et al. (2016), sementara penelitian mengenai kemungkinan terjadinya banjir rob di wilayah Probolinggo berdasarkan data oseanografi dan meteorologi belum pernah dilakukan. Perlu adanya kajian untuk melihat sejauh mana potensi kejadian rob di wilayah tersebut sebagai bahan masukan bagi pemerintah setempat dalam menanganinya.

Penelitian ini bertujuan untuk mengetahui potensi terjadinya banjir rob di 
wilayah pesisir Probolinggo berdasarkan data parameter oseanografi serta membandingkan kondisinya saat musim Barat dan musim Timur berdasarkan data meteorologi. Kajian ini penting mengingat rob atau banjir pasang air laut telah memberikan dampak serius terhadap komunitas pesisir di wilayah terdampak akibat perubahan lingkungan dan sosial-ekonomi (Supriyadi and Sandra, 2015).

\section{METODE PENELITIAN}

\subsection{Waktu dan Tempat Penelitian}

Penelitian dilakukan dalam 2 tahap yaitu tahap pengumpulan dan pengolahan data yang dilakukan pada Juni - Desember 2012 dan tahap pembangunan simulasi rob beserta analisa lebih lanjut pada November 2016. Wilayah kajian meliputi pesisir Probolinggo mulai dari desa Gending sampai desa Randutatah, dengan batas posisi geografis antara $113,28^{\circ}-113,5^{\circ} \mathrm{BT}$ dan $7,5^{\circ}$ $-7,8^{\circ} \mathrm{LS}$ (Gambar 1).

\subsection{Bahan dan Data}

Data-data oseanografi dan meteorologi yang digunakan dalam penelitian ini meliputi data pasut selama 7 tahun (2004 - 2011) dari Stasiun Maritim II Perak Surabaya ditambah data angin di 3 titik yang tersebar di Perairan Probolinggo (OM1, OM2, dam OM3) selama 9 tahun (2002 2011) (Gambar 1). Data topografi Probolinggo diperoleh dari SRTM (Shuttle Radar Topography Mission) 90 m Digital Elevation Database V4.1 dengan resolusi $0.000833^{\circ} \times 0.000833^{\circ}(90 \mathrm{~m} \mathrm{x} 90 \mathrm{~m}$ ) (Jarvis et al., 2008).

\subsection{Analisis Data}

Data pasut diolah dan dianalisa menggunakan WorldTide (Boon, 2006) yang menerapkan metode Least Square untuk memperoleh konstituen-konstituen harmonik untuk diturunkan menjadi rerata tinggi muka air seperti Mean Highest High Water Spring (MHHWS) - rerata air tinggi tertinggi saat pasang purnama, Mean Highest High Water Neap (MHHWN) - rerata air tinggi tertinggi saat pasang perbani, Mean Sea Level (MSL) - rerata tinggi air, Mean Lowest Low Water Spring (MLLWS) - rerata air rendah terendah saat pasang purnama, Mean Lowest Low Water Neap (MLLWN) - rerata air rendah terendah saat pasang perbani. Angin digambarkan melalui diagram mawar (rose diagram). Gelombang diturunkan dari data angin, menurut Stewart (2003) komponenkomponen gelombang dapat ditentukan dari data angin karena adanya keterkaitan antara angin dan gelombang di perairan.

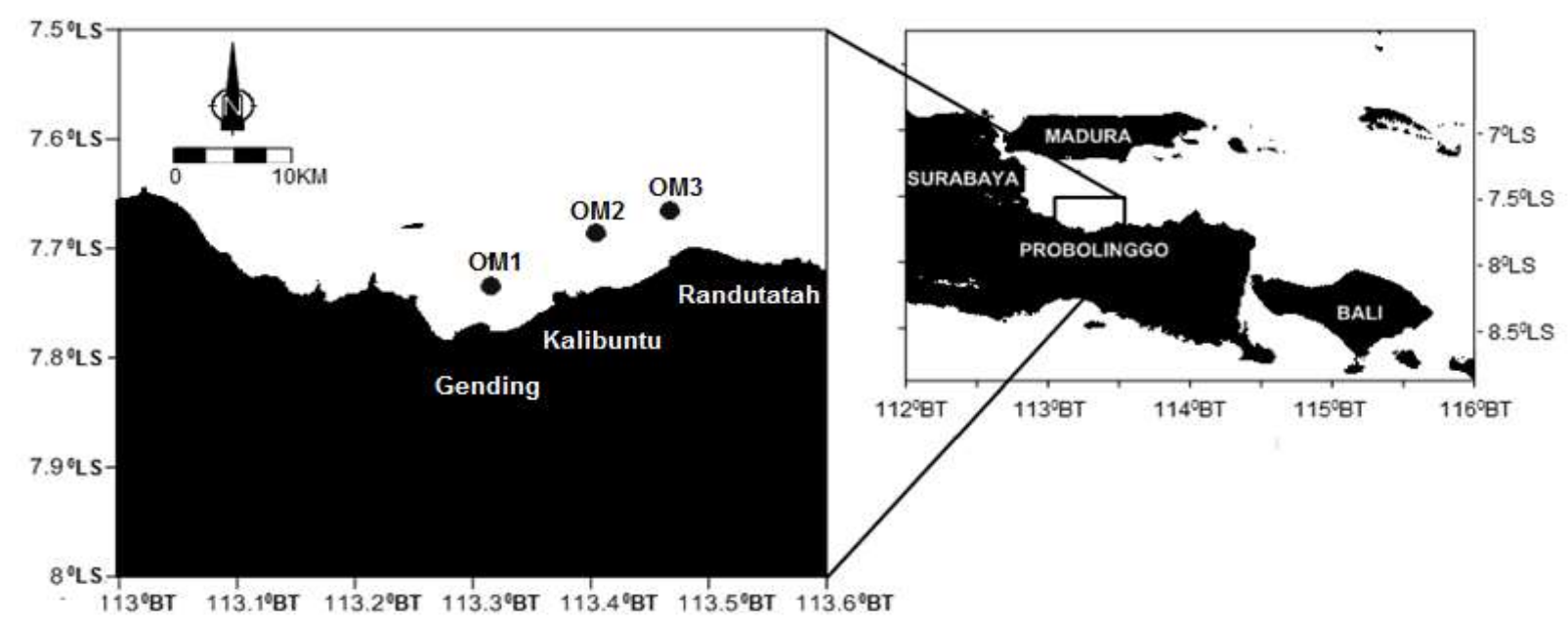

Gambar 1. Wilayah kajian dan titik-titik pengamatan oseanografi dan meteorologi (OM1 OM3). 
Tinggi gelombang signifikan dihitung dengan metode SMB setelah nilai fetch efektif diperoleh melalui persamaan (Triatmodjo, 1999):

$\frac{g H m_{0}}{U_{a}{ }^{2}}=1,6 \times 10^{-3} x$

$\frac{g T m}{U_{a}{ }^{2}}=2,857 \times 10^{-1} \times\left(\frac{g F}{U_{a}^{2}}\right)^{\frac{1}{a}}$.

Keterangan:

$g$ : Percepatan gravitasi $\left(9,8 \mathrm{~m} / \mathrm{s}^{2}\right)$

$H m_{0}$ : Tinggi gelombang signifikan (m)

$T m$ : Periode gelombang puncak (detik)

F : Panjang fetch (m)

$U_{a} \quad:$ Kecepatan angin (m/detik)

Panjang fetch yang digunakan dalam penghitungan tinggi gelombang adalah panjang fetch efektif (Triatmodjo, 1999).

$F_{\text {eff }}=\frac{\sum X i \cos \alpha}{\sum \cos \alpha}$

Keterangan:

$F_{\text {eff }}$ : Panjang fetch efektif (m)

$X i \quad$ : Panjang segmen fetch yang diukur dari titik observasi gelombang ke ujung akhir fetch

$\alpha \quad$ : Deviasi pada kedua sisi arah angin, dengan menggunakan pertambahan $6^{\circ}$ sampai $42^{\circ}$ pada kedua sisi arah angin

Potensi daerah genangan digambarkan berdasarkan tinggi muka air laut total (tinggi muka laut ditambah dengan tinggi gelombang) yang dioverlay dengan data topografi. Metode seperti ini lazim dilakukan dalam pemetaan banjir rob di pesisir sebagaimana yang dilakukan oleh (Nugraha et al., 2015). Pugh (1987) menyatakan bahwa pemetaan resiko banjir rob di wilayah pesisir dilakukan dengan memprediksi tinggi muka air tertinggi (HHWL/Highest Hight Water Level) dari data pasang surut dan rerata tinggi muka air laut (MSL). Marfai (2003) berpendapat bahwa pengukuran muka air tertinggi merupakan dasar bagi penentuan potensi rob sementara Xie et al. (2019) menyebutkan bahwa kombinasi interaksi pasut dan gelombang mengakibatkan kenaikan tinggi gelombang dekat pantai. Kondisi banjir rob pada musim Barat dan Timur dibandingkan melalui perbandingan kondisi cuaca (meteorologi) yang meliputi angin dan gelombang.

\section{HASIL DAN PEMBAHASAN}

\subsection{Pasang Surut}

Hasil perhitungan dari analisis pasang surut menunjukkan nilai bilangan Formzahl perairan Jawa Timur selama tahun 2004 - 2011 adalah 0,82. Hasil ini tidak berbeda jauh dengan yang dihasilkan oleh Kusmanto et al. (2016) dalam kajian mengenai pasut Probolinggo yang menghasilkan bilangan Formzahl 0,85 sehingga tipe pasut perairan Probolinggo dikategorikan ke dalam tipe campuran condong ke harian ganda. Hal ini berarti bahwa perairan Jawa Timur mengalami dua kali pasang dan dua kali surut dalam satu hari dengan perbedaan tinggi (amplitudo) dan interval yang berbeda.

Bowden (1983) menyatakan bahwa resultan dari gaya-gaya pembangkit pasut merupakan sebuah fungsi waktu rumit yang dapat diuraikan dalam bentuk penjumlahan dari komponen-komponen harmonik dalam jumlah yang besar. Komponen harmonik pasut beserta tinggi muka laut yang diperoleh dari data pasut tahun 2004 - 2011 disajikan pada Tabel 1.

Konstituen pasang surut yang dominan berdasarkan Tabel 2 menunjukkan bahwa komponen M2 (komponen utama bulan) dan K1 (komponen matahari-bulan) merupakan komponen dominan (amplitudo terbesar). Hal ini menunjukkan bahwa pengaruh perubahan dan kedudukan dari 
bulan dan matahari sangat mempengaruhi ketinggian muka air di wilayah tersebut.

Hasil penghitungan ketinggian elevasi-elevasi muka laut wilayah perairan Probolinggo tersebut menunjukkan bahwa banjir rob di pesisir Probolinggo sangat mungkin terjadi terutama saat pasang purnama karena topografi daerahnya yang relatif lebih rendah dari nilai rata-rata muka air tertinggi saat pasang purnama/MHHWS (0,73 m) (Gambar 2).

Keakuratan dalam identifikasi kerentanan wilayah terdampak banjir akan lebih meningkat ketika kajian didasarkan pada data topografi tingkat tinggi (Beach and Gesch, 2009). Nugroho (2013) sendiri menggunakan data MSL dan penurunan tanah untuk menentukan luasan genangan banjir rob di Semarang sementara Handoyo et al. (2016) menggunakan parameter HHWL yang dikoreksi MSL untuk membuat model genangannya.
Tabel 1. Beberapa komponen harmonik dan tinggi muka laut dari data pasut Probolinggo 2004 - 2011 hasil analisa Least Square dengan WorldTide (Boon, 2006).

\begin{tabular}{ccc}
\hline $\begin{array}{c}\text { Komponen } \\
\text { Pasut }\end{array}$ & $\begin{array}{c}\text { Amplitudo } \\
(\mathrm{m})\end{array}$ & $\begin{array}{c}\text { Fasa } \\
\text { (derajat) }\end{array}$ \\
\hline O1 & 0,27 & 211,765 \\
P1 & 0,14 & 324,84 \\
K1 & 0,45 & 288,35 \\
N2 & 0,16 & 152,49 \\
M2 & 0,59 & 264,26 \\
S2 & 0,29 & 330,12 \\
K2 & 0,05 & 123,57 \\
M4 & 0,001 & 60,59 \\
MS4 & 0,003 & 215,88 \\
\hline
\end{tabular}
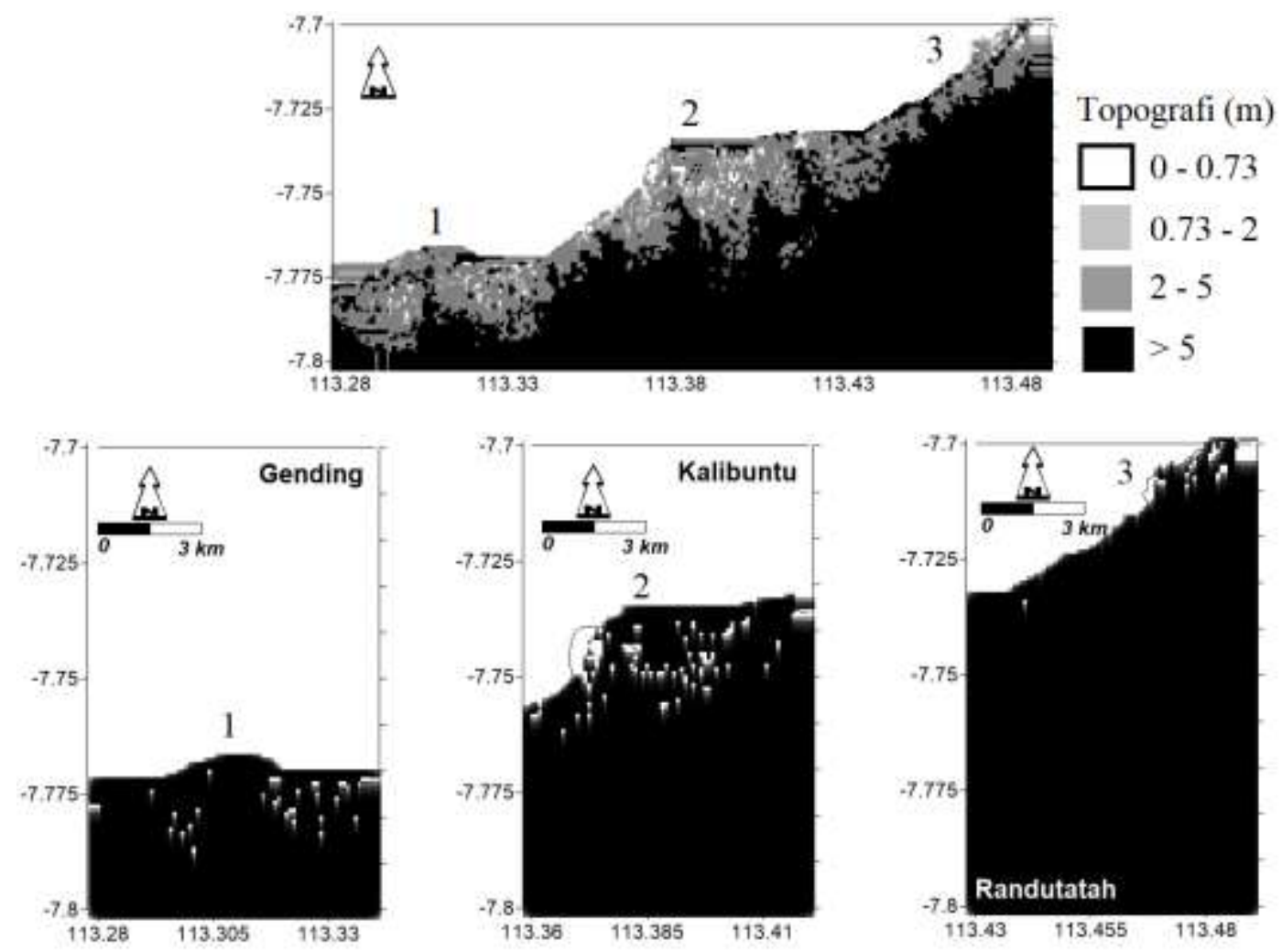

Gambar 2. Topografi daerah pesisir Probolinggo (atas) dan beberapa titik yang rentan banjir rob (bintik-bintik putih) karena ketinggiannya yang lebih rendah $(<0,73 \mathrm{~m})$ dari rata-rata tertinggi muka air saat pasang purnama $(0,73 \mathrm{~m})$. 
Hasil penggambaran daerah genangan (Gambar 2) menunjukkan bahwa desa Kalibuntu merupakan wilayah terdampak paling parah. Hal ini diperkuat dengan hasil kajian Supriyadi and Sandra (2015) yang menunjukkan bahwa ber-dasarkan pada hasil interpretasi data rekam Landsat 7 ETM pada tahun 2000 dan 2006, erosi yang terjadi di Kalibuntu sekitar $-4,99 \mathrm{~m} /$ tahun, paling cepat dibandingkan dengan desa Gending (-1,42 $\mathrm{m} /$ tahun) dengan akresi sebesar $+1,3 \mathrm{~m} /$ tahun terjadi di desa Randutatah (Tabel 2).

Tabel 2. Laju perubahan garis pantai pesisir Probolinggo berdasarkan pada Landsat 7 ETM tahun 2000 dan tahun 2006 (Supriyadi and Sandra, 2015).

\begin{tabular}{lccc}
\hline \multirow{2}{*}{ Desa } & \multicolumn{3}{c}{ Perubahan Garis Pantai (m) } \\
\cline { 2 - 4 } & Erosi & Akresi & $\begin{array}{c}\text { Laju } \\
\text { (m/tahun) }\end{array}$ \\
\hline Randutatah & 10,89 & 19,67 & $+1,3$ \\
Kalibuntu & 70,96 & 40,98 & $-4,99$ \\
Gending & 50 & 41,47 & $-1,42$ \\
\hline
\end{tabular}

Diperlukan analisis lebih lanjut mengenai penggambaran daerah-daerah genangan akibat banjir pasang tersebut melalui data hidrologi, geologi, dan aspek geoteknik agar memberikan hasil yang lebih optimal sebagai masukan kepada pemerintah atau PEMDA setempat sehingga akan lebih serius dalam menangani masalah banjir rob di Probolinggo.

Potensi kejadian rob di pesisir Probolinggo ini semestinya menjadi perhatian semua pihak khususnya pemerintah daerah setempat dan warga sekitar terlebih bila laju kenaikan muka air laut akibat perubahan iklim (Climate Change) meningkat. Kenaikan muka air laut tidak hanya meningkatkan debit air, melainkan frekuensi kejadiannya (Buchanan et al., 2017). Beberapa kajian (Kriebel et al., 2015; Wdowinski et al., 2016; Dahl et al., 2017) telah menunjukkan bagaimana kenaikan muka laut telah meningkatkan frekuensi kejadian banjir rob di pesisir disamping banjir karena hujan deras. Bencana banjir akibat kenaikan muka laut telah mempengaruhi $10 \%$ populasi bumi, sekitar 700 jiwa yang hidup di pesisir (McGranahan et al., 2007). Beberapa kajian (Weiss et al., 2011; Hinkel et al., 2014; Reguero et al., 2015) menunjukkan bagaimana kenaikan muka air laut akan membawa dampak yang besar dan berbahaya terhadap wilayah pesisir dalam beberapa tahun. Cayan et al. (2008) memprediksi kenaikan muka air laut global meningkat sekitar $20 \mathrm{~cm}$ dalam 100 tahun. Lebih jauh, Nicholls (2002) menyebutkan bahwa pada tahun 2100 sekitar 16-388 juta orang akan terdampak banjir per-tahunnya pada skenario tinggi muka laut pertengahan $(55 \mathrm{~cm})$ dan lebih dari 510 juta orang/tahun pada skenario tinggi muka laut tertinggi (96 $\mathrm{cm})$ sementara untuk kasus Probolinggo, Hasil kajian resiko rob oleh Supriyadi and Sandra (2015) di wilayah ini menunjukkan bahwa beberapa sektor terdampak yang akan mengalami kerugian adalah pertanian (sawah), tambak, dan pemukiman (Tabel 3). Beberapa kajian (Debernard and Røed, 2008; Gaslikova et al., 2013; Prime et al., 2015; Vousdoukas et al., 2016) menunjukkan bahwa intensitas kejadian cuaca ekstrem akan memperburuk dampak kenaikan tinggi muka laut di wilayah pesisir sehingga kajian terhadap kondisi atmosfer di Probolinggo juga perlu dilakukan untuk melihat lebih jauh mengenai kondisi rob Probolinggo.

\subsection{Angin}

Kondisi angin dikedua musim digambarkan melalui stickplot (Gambar 3) dan diagram mawar/rose diagram (Gambar 4 dan 5). Berbeda dengan arus, tanda panah pada vektor angin menunjukkan arah darimana angin tersebut berasal. Data angin yang digambarkan merupakan data 5 tahun (2005 - 2010) sehingga diperoleh 5 musim Barat dan 5 musim Timur. Pertengahan musim Timur (bulan Juli) ditandai dengan garis putus-putus pada stickplot (Gambar 3). 
Tabel 3. Daerah terdampak banjir rob Probolinggo (Supriyadi and Sandra, 2015).

\begin{tabular}{llcccc}
\hline \multirow{2}{*}{ No. } & \multirow{2}{*}{ Desa } & \multicolumn{3}{c}{ Daerah Genangan (ha) } & Total (ha) \\
& & Sawah & Tambak & Pemukiman & \\
\hline 1. & Gending & 0,46 & 14,14 & - & 14,59 \\
2. & Kalibuntu & 0,35 & 54,44 & 33,05 & 87,84 \\
3. & Randutatah & - & 32,20 & - & 32,20 \\
Total & & 0,81 & 102,78 & 33,05 & 136,64 \\
& & $(0,59 \%)$ & $(75,22 \%)$ & $24,19 \%)$ & $(100 \%)$ \\
\hline
\end{tabular}

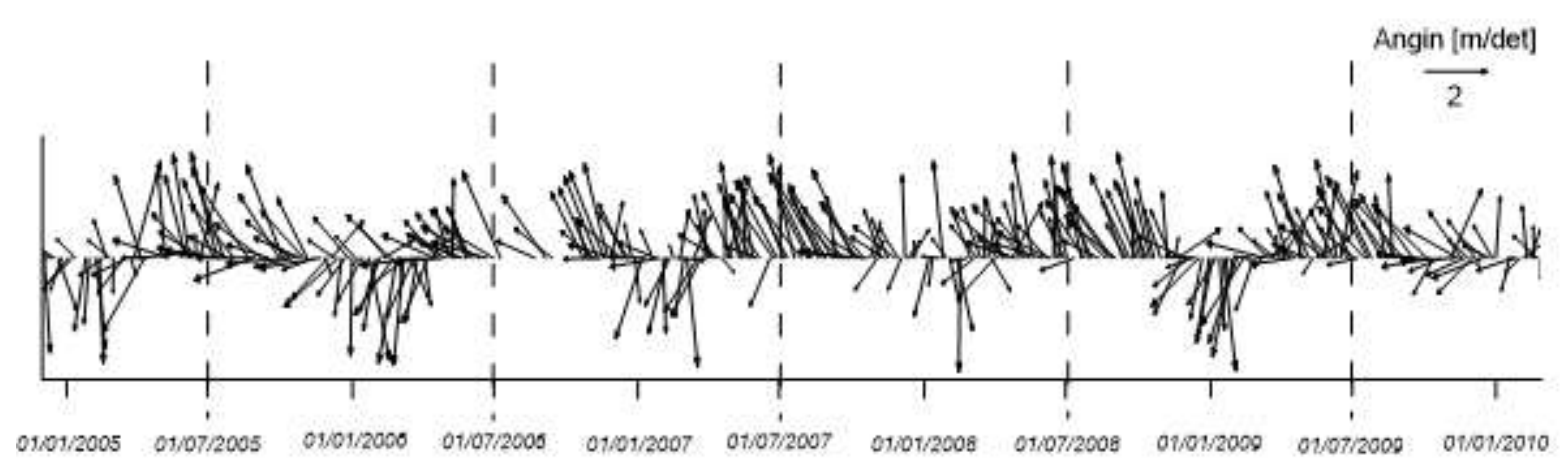

Gambar 3. Stickplot angin di pesisir Probolinggo dari tahun 2005 hingga 2010. Garis putusputus menandai pertengahan musim Timur atau bulan Juli. (catatan: arah vektor angin menunjukkan arah darimana angin tersebut berasal).

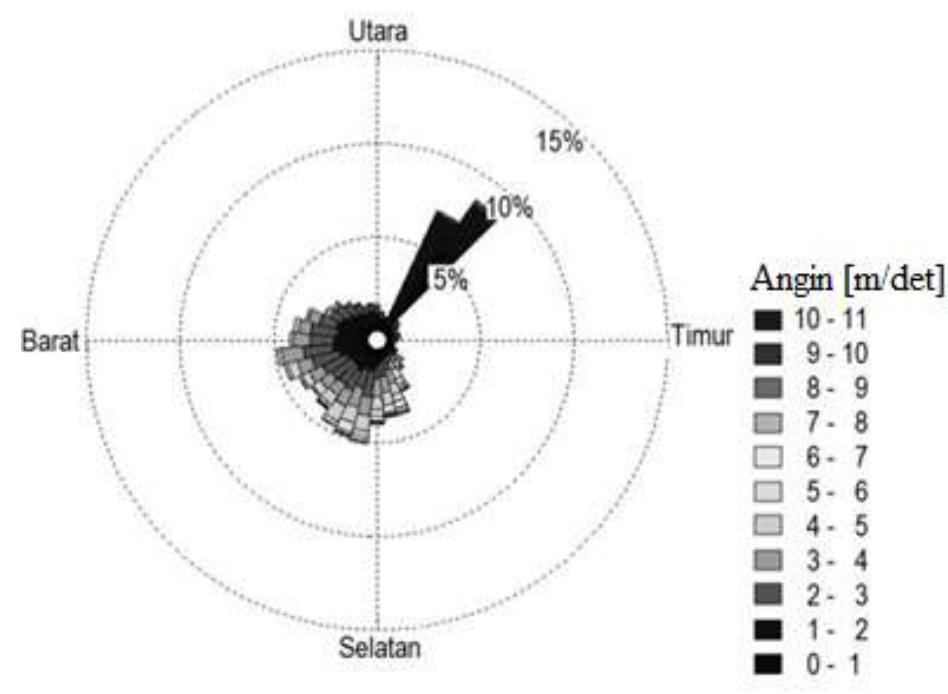

Gambar 4. Diagram mawar (rose diagram) angin pada musim Barat di pesisir Probolinggo dari tahun 2005 hingga 2010.

\subsubsection{Angin Musim Barat}

Diagram mawar (Wind Rose) untuk angin selama tahun 2004 - 2010 di pesisir Probolinggo pada musim barat menunjukkan bahwa arah angin dominan berasal dari Barat Daya dan Selatan (Gambar 3). Wyrtki (1961) menyatakan bahwa pada Musim Barat, angin di wilayah Indonesia memiliki arah dari Utara ke Selatan karena tekanan di belahan bumi selatan atau Australia lebih rendah daripada di Utara (Asia). Kondisi angin pada bulan-bulan musim Barat ini akan lebih jelas terlihat pada diagram mawar (Gambar 4). 
Berdasarkan pada diagram mawar tersebut, angin dominan yang berhembus pada bulan-bulan di musim Barat didominasi oleh angin yang berasal dari arah Barat Daya selama tahun 2004-2010 dengan kecepatan 0 - $7 \mathrm{~m} /$ det (Gambar 4). Angin yang berasal dari Timur Laut pernah tercatat dengan kecepatan yang relatif tinggi, yaitu $9-11$ $\mathrm{m} /$ det dan mengisi sekitar 7,5 - 8,5\% kejadian (Gambar 4).

\subsubsection{Angin Musim Timur}

Arah angin dominan pada musim Timur berasal dari Barat Laut (area sekitar garis putus pada Gambar 3). Kondisi ini sesuai dengan yang dikemukakan oleh Wyrtki (1961) mengenai sistem angin di Indonesia yang memiliki arah dari Selatan ke Utara pada Musim Timur karena tekanan di belahan bumi selatan atau Australia lebih tinggi daripada di Utara (Asia). Diagram mawar menunjukkan bagaimana angin yang berasal dari Barat Laut ini mendominasi hampir seluruh kejadian angin pada musim Timur selama tahun 2005 hingga 2010. Meski demikian, angin berkekuatan $8 \mathrm{~m} / \mathrm{det}$ hingga $9 \mathrm{~m} /$ det tercatat berasal dari Timur Laut dan Timur namun dengan frekuensi kejadian yang relatif rendah atau hanya sekitar 5 - 15\% kejadian (Gambar 5).
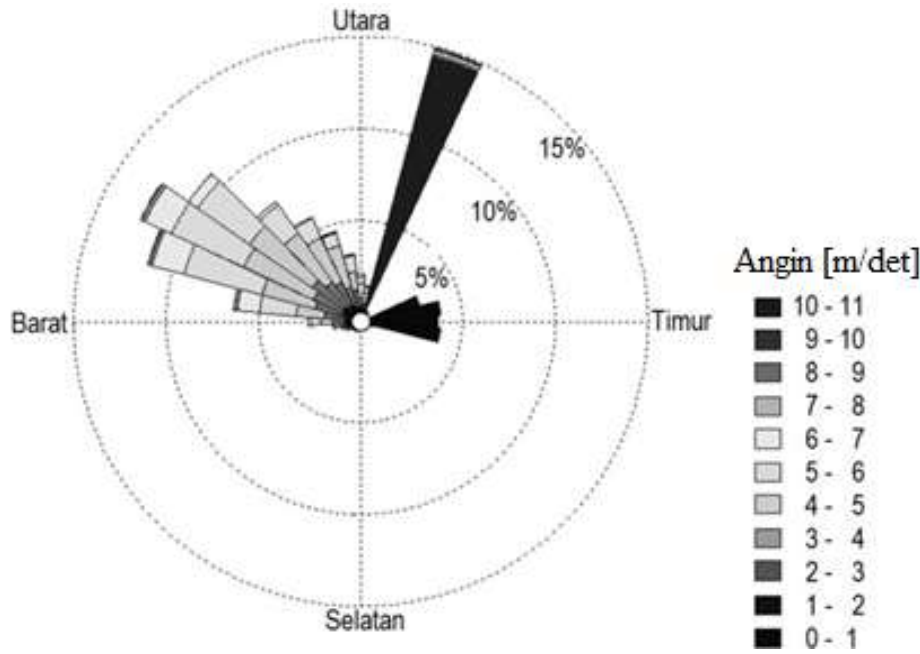

Gambar 5. Diagram mawar (rose diagram) angin musim Timur pesisir Probolinggo dari tahun 2005 hingga 2010.

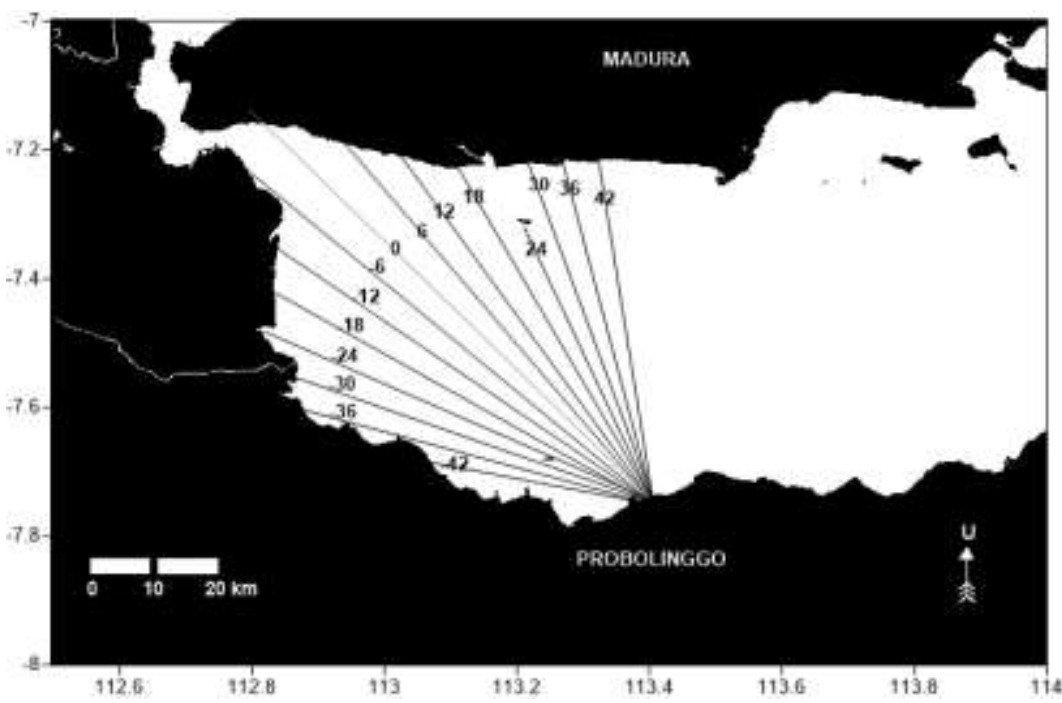

Gambar 6. Sudut fetch (dalam derajat) yang memungkinkan untuk wilayah perairan Probolinggo. 


\subsection{Gelombang}

Angin di perairan Probolinggo selama tahun 2004-2010 yang memungkinkan dapat membangkitkan gelombang ke arah pantai adalah angin yang berasal dari Barat Laut yang menuju Tenggara atau angin yang terjadi pada musim Timur sehingga garis fetch utama $\left(0^{\circ}\right)$ ditarik searah Barat Laut dari daerah kajian hingga ke daratan terjauh dalam arah tersebut diikuti dengan garis $6^{\circ}$ dan kelipatannya di sisi kiri dan kanan garis fetch utama (Gambar 6).

Panjang fetch efektif yang mungkin untuk perairan Probolinggo berdasarkan persamaan (3) adalah 64,29 km (Tabel 4). Hasil perhitungan tinggi gelombang signifikan melalui persamaan (1) dan (2) berdasarkan panjang fetch efektif di atas menunjukkan bahwa pada Musim Timur (Juni, Juli, dan Agustus) hingga awal musim peralihan II nilainya relatif lebih tinggi (ratarata $0,2 \mathrm{~m}$ ) dibandingkan dengan kondisi pada musim Barat (rata-rata tinggi gelombang sekitar 0,13 m) (Gambar 7).

Tabel 4. Hasil penghitungan panjang fetch efektif.

\begin{tabular}{cccc}
\hline$\alpha\left(^{\circ}\right)$ & $\mathrm{Xi}(\mathrm{km})$ & $\cos \alpha$ & $\mathrm{xi}_{-} \cos \alpha$ \\
\hline 42 & 56,26 & 0,74 & 41,80 \\
36 & 57,62 & 0,80 & 46,61 \\
30 & 58,31 & 0,86 & 50,49 \\
24 & 60,06 & 0,91 & 54,86 \\
18 & 60,68 & 0,95 & 57,71 \\
12 & 66,23 & 0,97 & 64,78 \\
6 & 74,67 & 0,99 & 74,26 \\
0 & 89,67 & 1 & 89,67 \\
-6 & 88,73 & 0,99 & 88,24 \\
-12 & 75,08 & 0,97 & 73,43 \\
-18 & 70,92 & 0,95 & 67,44 \\
-24 & 65,9 & 0,91 & 60,20 \\
-30 & 59,81 & 0,86 & 51,79 \\
-36 & 37,33 & 0,80 & 30,20 \\
-42 & 23,05 & 0,74 & 17,12 \\
Jumlah & & 13,51 & 868,67 \\
\hline Fetch Efektif & \multicolumn{2}{c}{64,29} \\
\hline
\end{tabular}

Musim Barat memiliki tinggi gelombang maksimum sebesar $0,71 \mathrm{~m}$ dan rata-rata sebesar $0,13 \mathrm{~m}$ (Tabel 5). Gelombang tinggi (> rata-rata) tidak terjadi sepanjang musim melainkan hanya terjadi saat-saat tertentu saja. Frekuensi kejadiannya sekitar 1.670 hari data. Musim Timur memiliki tinggi gelombang maksimum 0,57 $\mathrm{m}$ dengan rata-rata sebesar $0,2 \mathrm{~m}$ (Tabel 5) namun frekuensi kejadiannya cukup tinggi yaitu sebanyak 2.654 hari data sehingga banjir rob akan lebih parah kondisinya pada musim Timur karena kehadiran gelombang tinggi yang cukup intens.

Tabel 5. Hasil Penghitungan Tinggi gelombang signifikan (dalam meter) perairan Probolinggo selama 20042010.

\begin{tabular}{lcc}
\hline \multicolumn{1}{c}{ Tinggi } & $\begin{array}{c}\text { Musim } \\
\text { Barat }\end{array}$ & $\begin{array}{c}\text { Musim } \\
\text { Timur }\end{array}$ \\
\hline Min & 0,00014 & 0,00077 \\
Max & 0,71 & 0,57 \\
Rata-rata & 0,13 & 0,2 \\
Standar Deviasi & 0,11 & 0,07 \\
\hline
\end{tabular}

Potensi banjir rob dengan menggunakan tinggi gelombang signifikan ini juga pernah dilakukan oleh Perini et al. (2016) yang menggunakan total ketinggian muka air laut untuk mengevaluasi tingkat kerentanan wilayah pesisir terhadap banjir rob dengan menjumlahkan gelombanggelombang tinggi dan ketinggian rata-rata pasang surut kemudian di-overlay dengan data topografi DEM (Digital Elevation Model) daerah kajiannya.

\subsection{Curah Hujan}

Penyebab banjir rob bukan hanya dari hujan, melainkan banjir-banjir yang biasa terjadi di daratan dan curah hujan yang tinggi akan mengakibatkan kondisi banjir rob yang lebih parah. Banjir rob yang disertai hujan deras dalam jangka waktu yang lama akan mengakibatkan kondisi yang semakin parah bahkan jika di sekitar daerah-daerah terdampak terdapat banyak sungai yang mengakibatkan sungai-sungai tersebut meluap (NOAA, 2017).

Curah hujan yang relatif tinggi $(>300$ $\mathrm{mm})$ terjadi pada bulan Januari, Februari, Maret, dan Desember atau pada musim- 
musim Barat setiap tahunnya (Tabel 6), (Gambar 8). dengan nilai tertinggi di bulan Februari

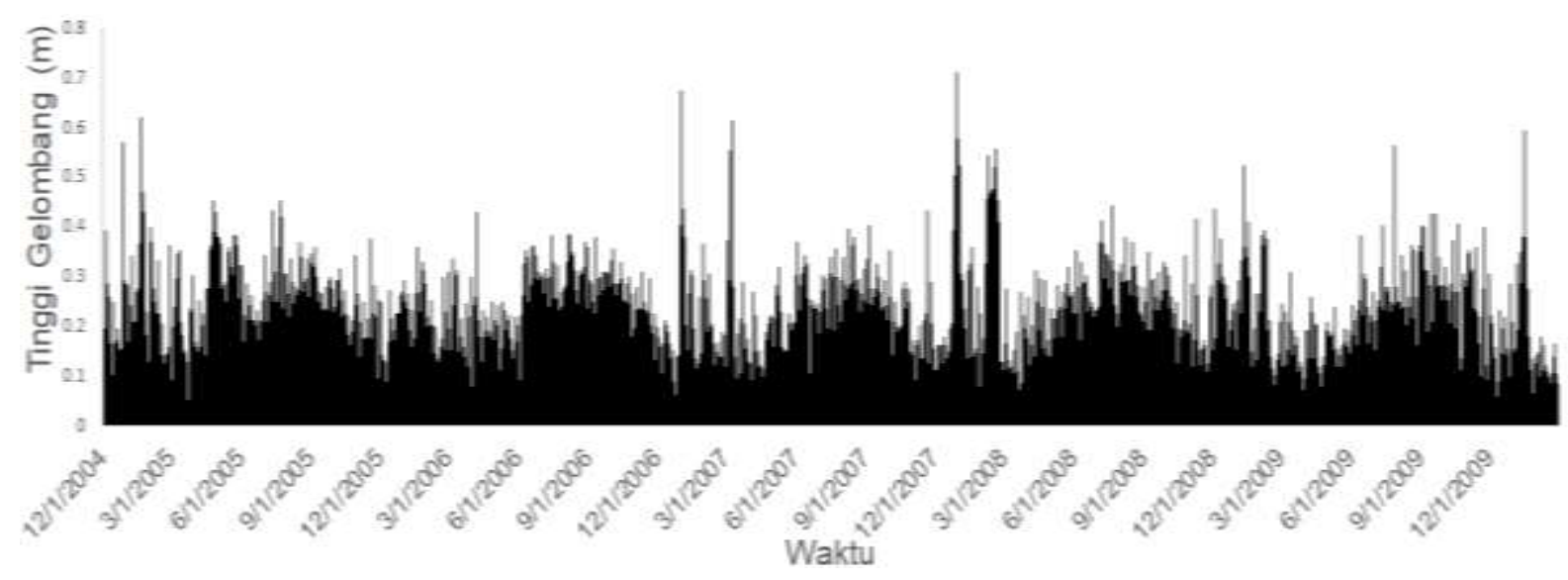

Gambar 7. Tinggi gelombang signifikan periode 2004-2010 perairan Probolinggo sebagai hasil perhitungan dengan metode SMB.

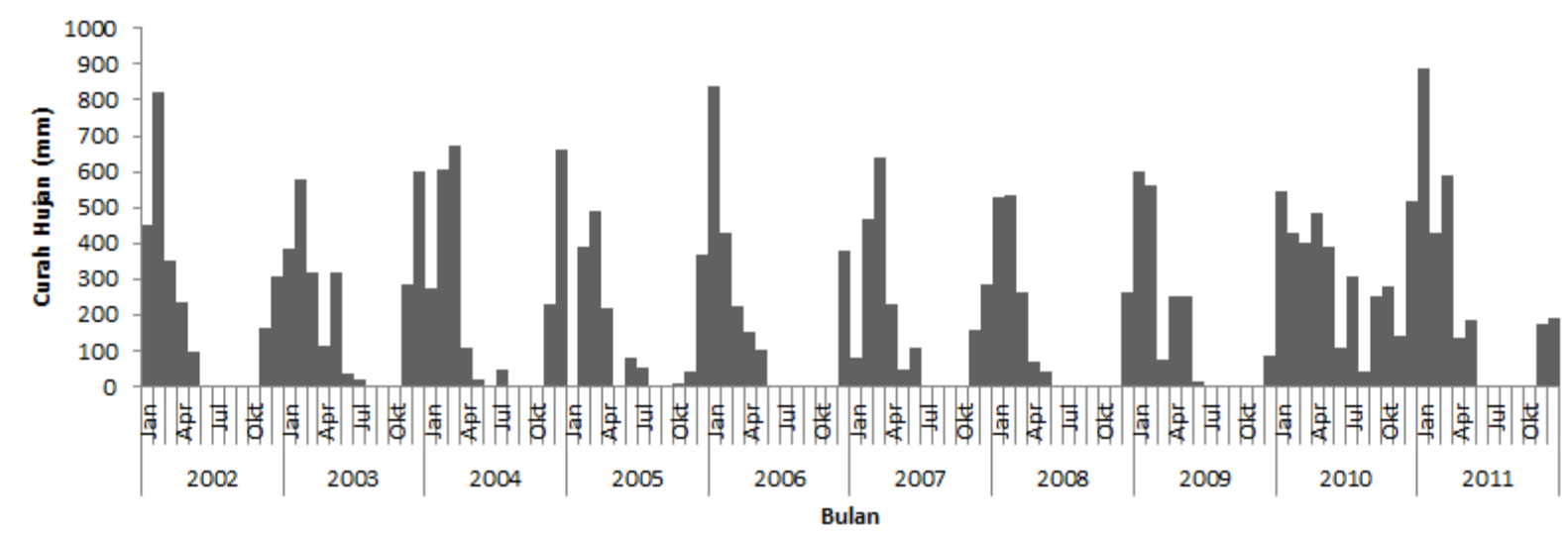

Gambar 8. Curah hujan Probolinggo selama tahun 2002-2011.

Tabel 6. Rekapitulasi curah hujan (dalam $\mathrm{mm}$ ) per-bulan selama 2002-2011 untuk Daerah Probolinggo dan sekitarnya (Sumber data: BMKG Bandara Juanda, Surabaya-Jawa Timur berdasarkan data Stasiun Klimatologi Probolinggo).

\begin{tabular}{ccccccccccccc}
\hline Tahun & Jan & Feb & Mar & Apr & May & Jun & Jul & Aug & Sep & Oct & Nov & Dec \\
\hline 2002 & 453 & 822 & 351 & 235 & 98 & 0 & 0 & 0 & 0 & 0 & 165 & 309 \\
2003 & 384 & 580 & 318 & 117 & 317 & 38 & 20 & 0 & 0 & 0 & 287 & 599 \\
2004 & 276 & 609 & 670 & 110 & 22 & 0 & 49 & 0 & 0 & 0 & 228 & 664 \\
2005 & 0 & 393 & 489 & 217 & 0 & 79 & 51 & 0 & 0 & 10 & 45 & 367 \\
2006 & 836 & 430 & 224 & 154 & 104 & 0 & 0 & 0 & 0 & 0 & 0 & 380 \\
2007 & 82 & 467 & 637 & 230 & 47 & 110 & 0 & 0 & 0 & 0 & 156 & 286 \\
2008 & 528 & 535 & 264 & 71 & 44 & 0 & 0 & 0 & 0 & 0 & 0 & 266 \\
2009 & 602 & 563 & 75 & 250 & 255 & 12 & 0 & 0 & 0 & 0 & 0 & 86 \\
2010 & 547 & 429 & 402 & 486 & 392 & 109 & 307 & 41 & 255 & 282 & 143 & 519 \\
2011 & 888 & 427 & 589 & 137 & 187 & 0 & 0 & 0 & 0 & 0 & 173 & 193 \\
\hline Rerata & 459,6 & 525,5 & 401,9 & 200,7 & 146,6 & 34,8 & 42,7 & 4,1 & 25,5 & 29,2 & 119,7 & 366,9 \\
\hline
\end{tabular}


Curah hujan yang terjadi pada musim timur (Juni, Juli, Agustus) relatif lebih rendah (Gambar 8) dengan jumlah hari hujan yang sangat sedikit (Tabel 6). Nilai paling rendah terjadi pada bulan Agustus setiap tahunnya. Hal ini sesuai dengan data statistik klimatologi tahun 2016 yang dikeluarkan oleh BPS Kab. Probolinggo (2016), disebutkan bahwa curah hujan pada bulanbulan musim Barat (Januari dan Februari) lebih tinggi (Januari: $449 \mathrm{~mm}^{3}$ (2015), 238 $\mathrm{mm}^{3}$ (2016); Februari: $337 \mathrm{~mm}^{3}$ (2015), 365 $\mathrm{mm}^{3}$ (2016) daripada pada bulan-bulan musim Timur (Juni, Juli, Agustus) yang masing-masing curah hujannya $180 \mathrm{~mm}^{3}$, $112 \mathrm{~mm}^{3}$, dan $0 \mathrm{~mm}^{3}$ pada tahun 2015 . Sementara pada tahun 2016 tidak ada hari hujan pada bulan-bulan tersebut atau curah hujan $0 \mathrm{~mm}^{3}$ (BPS Kab, Probolinggo, 2016). Hari hujan pada bulan-bulan musim Barat pun lebih banyak pada (Januari 13 hari, Februari 19 hari, Maret 21 hari) dibandingkan dengan bulan-bulan musim Timur yang tidak memiliki hari hujan (BPS Kab. Probolinggo, 2016).

\subsection{Hasil Rekapitulasi Kondisi Oseanografi dan Meteorologi}

Hasil rekapitulasi analisis dari berbagai kondisi oseanografi (pasang surut dan gelombang) dan meteorologi (angin dan curah hujan) menunjukkan bahwa Musim Barat dan Musim Timur memiliki kondisi berbeda jika kejadian rob terjadi di daerah pesisir Probolinggo. Rob yang terjadi pada bulan-bulan musim Timur akan diperparah oleh angin kencang yang berkontribusi besar dalam membentuk gelombang-gelombang tinggi di wilayah pesisir Probolinggo (Tabel 7).

Tabel 7. Rekapitulasi analisa kondisi meteorologi.

\begin{tabular}{|c|c|c|}
\hline Faktor & Musim Barat & Musim Timur \\
\hline Angin & $\begin{array}{l}\text { Kecepatan angin rendah } \\
\text { sampai sedang sering terjadi, } \\
\text { Di samping itu angin sangat } \\
\text { kencang }(>10 \mathrm{~m} / \mathrm{s}) \text { memiliki } \\
\text { frekuensi kejadian yang cukup } \\
\text { tinggi, Arah angin dominan } \\
\text { berasal dari Barat Daya. } \\
\text { Melihat posisi geografis } \\
\text { Probolinggo yang terbentang } \\
\text { di sebelah Selatan, } \\
\text { perairannya mengindikasikan } \\
\text { bahwa angin ini memiliki } \\
\text { kontribusi kecil dalam } \\
\text { membangkitkan gelombang di } \\
\text { pesisir Probolinggo. }\end{array}$ & $\begin{array}{l}\text { Kecepatan angin sedang sampai kencang } \\
\text { sering terjadi. Arah angin dominan berasal dari } \\
\text { Barat Laut dan mengacu pada posisi } \\
\text { geografisnya, angin ini memiliki kontribusi } \\
\text { besar dalam membangkitkan gelombang- } \\
\text { gelombang tinggi di peisisr Probolinggo. }\end{array}$ \\
\hline Gelombang & $\begin{array}{l}\text { Gelombang tinggi (> rata- } \\
\text { rata) terjadi pada waktu } \\
\text { tertentu saja di } \text { bulan } \\
\text { Desember dan Januari. }\end{array}$ & $\begin{array}{l}\text { Gelombang tinggi terjadi dengan frekuensi } \\
\text { yang lebih tinggi sepanjang musim hingga } \\
\text { awal musim peralihan II. }\end{array}$ \\
\hline $\begin{array}{l}\text { Curah } \\
\text { hujan }\end{array}$ & $\begin{array}{l}\text { Curah hujan tinggi dengan } \\
\text { jumlah hari hujan yang } \\
\text { banyak/sering. }\end{array}$ & $\begin{array}{l}\text { Curah hujan relatif rendah dan hari hujan } \\
\text { terbilang jarang. }\end{array}$ \\
\hline
\end{tabular}


Hasil pengamatan dan penelusuran dari warga menunjukkan bahwa kejadian rob di Probolinggo, terutama di Desa Gending, Kali buntu, dan Randutatah hampir terjadi pada setiap pasang tinggi, yakni tanggal 15, 16, dan 17 penanggalan Hijriyah (pasang purnama). Dengan demikian, perlu kajian lebih lanjut terhadap faktor-faktor lain penyebab terjadinya rob di daerah ini seperti potensi penurunan tanah, faktor-faktor kelalaian manusia seperti penggunaan lahan yang keliru atau pembukaan lahan secara liar juga perlu dikaji lebih lanjut.

\section{KESIMPULAN}

Beberapa wilayah di pesisir Probolinggo, yaitu Desa Gending, Kalibuntu, dan Randutatah sangat berpotensi terkena banjir rob saat pasang tinggi, terutama saat pasang purnama karena topografinya yang lebih rendah dari tinggi muka laut. Berdasarkan hasil analisa data oseanografi (gelombang) dan meteorologi (angin dan curah hujan), kondisi banjir rob Probolinggo akan berbeda saat musim Barat dan Timur. Musim Timur (Juni, Juli, Agustus) adalah waktu yang memberikan dampak lebih buruk pada kejadian banjir rob di pesisir Probolinggo karena kehadiran angin kencang yang membangkitkan gelombang-gelombang tinggi di pesisir. Meski demikian, dampak banjir rob di bulan-bulan Musim Barat (Desember, Januari, Februari) tetap harus diwaspadai.

\section{UCAPAN TERIMA KASIH}

Ucapan terima kasih dan penghargaan sebesar-besarnya penulis ucapkan kepada Bapak Eko Prasetyo dari Stasiun Meteorologi Maritim Perak II Surabaya yang telah memberikan bantuan materi berupa data-data pasang surut dan meteorologi bagi penelitian ini.

\section{DAFTAR PUSTAKA}

Badan Penanggulangan Bencana Daerah Kabupaten Probolinggo (BPBD Kab. Probolinggo). 2016. Banjir rob di Desa Randu Tatah, Paiton Probolinggo. http://bpbd.probolinggokab.go.id/id/b erita/banjir-rob-di-desa-randu-tatahpaiton-probolinggo. [Diakses pada tanggal 17 April 2017].

Badan Pusat Statistik Kabupaten Probolinggo (BPS Kab. Probolinggo). 2016. Probolinggo dalam Angka 2016. BPS Kabupaten Probolinggo 2016. 134 p.

Boon, J.D. 2006. World tides user manual version 1.01 October 12, 2006, www.worldtidesandcurrents.com

[Diakses pada tanggal 17 Mei 2017].

Bowden, K.F. 1983. Physical oceanography of coastal waters. John Wiley \& Sons, Inc. Somerset - New Jersey. 302 p.

Brown, J.M., J. Wolf, and A. J. Souza. 2012. Past to future extreme events in Liverpool Bay: model projections from 1960-2100, Climatic Change, 111(2): 365-391. https://doi.org/10.1007/s10584-0110145-2

Buchanan, M.K., M. Oppenheimer, and R.E. Kopp. 2017. Amplification of flood frequencies with local sea-level rise and emerging flood regimes. Environ. Res. Lett., 12(6): 064009. https://doi.org/10.1088/17489326/aa6cb3

Cayan, D.R., P.D. Bromirski, and K. Hayhoe, M. Tyree, M.D. Dettinger, R.E. Flick. 2008. Climate change projections of sea level extremes along the California coast. Climatic Change, 87(1): 57-73. https://doi.org/10.1007/s10584-0079376-7 
Dahl K.A., M.F. Fitzpatrick, E. SpangerSiegfried. 2017. Sea level rise drives increased tidal flooding frequency at tide gauges along the U. S. East and Gulf Coasts: Projections for 2030 and 2045. J. PLoS ONE, 12(2): e0170949. https://doi.org/10.1371/journal.pone.0 170949

Debernard, J.B. and L.P. Røed. 2008. Future wind, wave and storm surge climate in the Northern Seas: a revisit, $J$. Tellus A: Dynamic Meteorology and Oceanography, 60(3): 427-438. https://www.tandfonline.com/doi/abs/ 10.1111/j.1600-0870.2007.00312.x

Gaslikova, L., I. Grabemann, and N. Groll. 2013. Changes in North Sea storm surge conditions for four transient future climate realizations, Nat. Hazards, 66(3): 1501-1518. https://doi.org/10.1007/s11069-0120279-1

Gesch, D.B. 2009. Analysis of lidar elevation data for improved identification and delineation of lands vulnerable to sealevel rise. J. of Coastal Res., 53: 4958. https://doi.org/10.2112/SI53006.1

Habibie, M.N., A. Hartoko, N.S. Ningsih, M.H. Siswanto, R. Kurniawan, A. Ramdhani, dan R.S.S. Sudewi. 2012. Simulasi rob di Semarang menggunakan model Hidrodinamika 2D. $J$. Meteorologi dan Geofisika, 13(2): 103-109.

http://doi.org/10.31172/jmg.v13i2.12 4

Handoyo, G., A.A.D. Suryoputro, dan P. Subardjo. 2016. Genangan banjir rob di Kecamatan Semarang Utara. $J$. Kelautan Tropis, 19(1): 55-59. https://doi.org/10.14710/jkt.v19i1.601

Hinkel, J., D. Lincke, A.T. Vafeidis, M. Perrette, R.J. Nicholls, R.S. Tol, B. Marzeion, X. Fettweis, C. Lonescu, and A. Levermann. 2014. Coastal flood damage and adaptation costs under 21 st century sea-level rise.
Proceedings of the National Academy of Sciences of the United States of America. J. PNAS, 111, (9): 32923297.

https://doi.org/10.1073/pnas.1222469 111

Jarvis, A., H.I. Reuter, A. Nelson, and E. Guevara. 2008. Hole-filled SRTM for the globe Version 4.

http://srtm.csi.cgiar.org. [Diakses 20 Juli 2012].

Komunikasi dan Informasi Sekretariat Daerah Pemerintah Kabupaten Probolinggo (KOMINFO SETDA PEMKAB Probolinggo).2016. Profil Kabupaten Probolinggo.

http://www.probolinggokab.go.id.

[Diakses pada tanggal 11 Agustus 2016].

Kriebel, D.L., J.D. Geiman, and G.R. Henderson. 2015. Future flood frequency under sea-level rise scenarios. J. of Coastal Res., 31(5): 1078-1083.

https://doi.org/10.2112/JCOASTRESD-13-00190.1

Kusmanto, E., M. Hasanudin, dan W.B. Setyawan. 2016. Amplifikasi pasang surut dan dampaknya terhadap perairan pesisir Probolinggo. $J$. Oseanologi dan Limnologi di Indonesia, 1(3): 69-80 pp.

Marfai, M A. 2003. GIS modelling of river and tidal flood hazards in a waterfront city case study: Semarang City, Central Java, Indonesia. Thesis. Master Science in, Natural Hazard Studies specialization. International Institute for Geo-Information Science and Earth Observation Enschede, Netherlands. 123 p.

Maulana, E. dan M. Hartanto. 2010. Pengolahan Data Tinggi Gelombang Signifikan. Modul Kuliah. Institut Pertanian Bogor. 15 p.

McGranahan, G., D. Balk, and B. Anderson. 2007. The rising tide: assessing the risks of climate change and human 
settlements in low elevation coastal zones. J. Environment and Urbanization, 19(1): 17-37. https://doi.org/10.1177/09562478070 76960

National Oceanic and Atmosferic Administration (NOAA). 2017. Overview - Causes of Coastal Flooding.

http://www.stormsurge.noaa.gov/over view_causes.html. [Diakses pada tanggal 10 maret 2017].

Nicholls, R.J. 2002. Analysis of global impacts of sea-level rise: a case study of flooding. Phys. and Chem. Earth, part A/B/C/, 27(32-34): 1455-1466. https://doi.org/10.1016/S14747065(02)00090-6

Nugraha A.L, P.B. Santosa, and T. Aditya. 2015. Dissemination of tidal flood risk map using online map in semarang. Procedia Environmental Sciences, 23: 64-71. https://doi.org/10.1016/j.proenv.2015. 01.010

Nugroho, S.H. 2013. Prediksi luas genangan pasang surut (rob) berdasarkan analisis data spasial di Kota Semarang, Indonesia. J. Lingkungan dan Bencana Geologi, 4(1): 71-87. http://jlbg.geologi.esdm.go.id/index.p hp/jlbg/article/download/51/53

Perini, L., L. Calabrese, G. Salerno, P. Ciavola, and C. Armaroli. 2016. Evaluation of coastal vulnerability to flooding: comparison of two different methodologies adopted by the EmiliaRomagna region (Italy). Nat. Hazards Earth Syst. Sci., 16(1): 181-194. https://doi.org/10.5194/nhess-16-1812016

Pratikno, N.S. dan W. Handayani. 2014. Pengaruh genangan banjir rob terhadap dinamika sosial ekonomi masyarakat Kelurahan Bandarharjo, Semarang. J. Teknik PWK, 3(2): 312318.
Prime T, J.M. Brown, A.J. Plater. 2015. Physical and economic impacts of sea-level rise and low probability flooding events on coastal communities. J. PLoS ONE, 10(2): e0117030. https://doi.org/10.1371/journal.pone.0 117030

Pugh, D.T. 1987. Tide, Surge and Mean Sea Level. A Handbook for Engineer and Scientist. John and Sons Ltd. Chichester. 472 p.

Reguero B.G., I.J. Losada, P. Díaz-Simal, F.J. Méndez, M.W. Beck. 2015. Effects of climate change on exposure to coastal flooding in Latin America and the Caribbean. J. PLoS ONE, 10(7): e0133409.

https://doi.org/10.1371/journal.pone.0 133409

Rofiq, M. 2016. Banjir rob menerjang lima desa, puluhan hektar tambak dan rumah terendam. https://news.detik.com/beritajawa-timur/3229146/banjir-robmenerjang-lima-desa-puluhan-hektartambak-dan-rumah-terendam. [Diakses pada tanggal 15 maret 2017].

Spanger-Siegfried, E., M.F. Fitzpatrick, and K. Dahl. 2014. Encroaching Tides: How sea-level rise and tidal flooding threaten U.S. East and Gulf Coast communities over the next 30 years. Cambridge, MA: Union of Concerned Scientists. $76 \mathrm{p}$.

Stewart, R. 2003. Introduction to physical oceanography. Department of oceanography. A \& M University Press. Texas. 352 p.

Supriyadi, I.H., and A. Sandra. 2015. Impacts and adaptation to climate change: a case study of coastal inundation at Probolinggo, East-Java. J. Coast zone manag., $18(1): 390$ - 398. https://doi.org/10.4172/24733350.1000398

Triatmodjo, B. 1999. Teknik Pantai. Beta Offset Press. Yogyakarta. 397 p. 
Vousdoukas, M.I., E. Voukouvalas, A. Annunziato, A. Giardino, and L. Feyen. 2016. Projections of extreme storm surge levels along Europe, $J$. Clim. Dyn., 47(9-10): 3171-3190. https://doi.org/10.1007/s00382-0163019-5

Wahyudi, S.I. 2007. Tingkat Pengaruh Elevasi Pasang Laut terhadap Banjir dan Rob di Kawasan Kaligawe Semarang. J. Riptek, 1(1): 27-34.

Wdowinski, S., R. Bray, B.P. Kirtman, and Z. Wu. 2016. Increasing flooding hazard in coastal communities due to rising sea level: case study of Miami Beach, Florida. Ocean and coastal management, 126: 1-8. https://doi.org/10.1016/j.ocecoaman.2 016.03 .002

Wicahyo, D. 2016. 56,8 Hektar Tambak Ikan dan Garam di Probolinggo Rusak Karena Banjir Rob. kraksaanonline.com. http://www.kraksaanonline.com/2016/06/568-hektartambak-ikan-dan-garam-di.html.

[Diakses pada tanggal 15 maret 2017].
Wyrtki, K. 1961. NAGA REPORT Vol. 2: scientific results of marine investigations of the South China Sea and the Gulf of Thailand 1959-1961. The University of California Scripps Institution of Oceanography. La Jolla, California. 225p.

Wolf, J. 2009. Coastal flooding: impacts of coupled wave-surge-tide models. Nat Hazards, 49(2): 241-260. https://doi.org/10.1007/s11069-0089316-5

Xie, Dongmei, Q. Zou, A. Mignone, and JD Macrae. 2019. Coastal Flooding from Wave Overtopping and Sea Level Rise Adaptation in the Northeastern USA. Coastal Engineering, 150: 3958.

https://doi.org/10.1016/j.coastaleng.2 019.02.001

Zuardin. 2017. Banjir rob: Potensi kerentanan lingkungan serta penanggulangannya. J. Tek. Lingk., 1(2): 58-66.

$\begin{array}{ll}\text { Received } & : 28 \text { March } 2018 \\ \text { Reviewed } & : \text { O7 July } 2018 \\ \text { Accepted } & : 25 \text { November } 2019\end{array}$ 
